\title{
SPACE DISTRIBUTION OF SOYBEAN SEED STORAGE POTENTIAL ${ }^{1}$
}

\author{
RAFAEL DE OLIVEIRA VERGARA ${ }^{2 *}$, ALEXANDRE GAZOLLA-NETO ${ }^{3}$, GIZELE INGRID GADOTTI ${ }^{4}$
}

\begin{abstract}
The objective of this study was to identify the spatial distribution of the physiological quality of soybean seeds during storage from a production field of 39 hectares using geostatistical techniques in the 2012/2013 harvest. Seeds were sampled at geo-referenced points for the determination of physiological quality and spatial dependence analysis. The results were submitted to analysis of descriptive statistics, Pearson's linear correlation and geostatistics. The grid of one point per hectare and a georeferenced sampling mesh with spacing of 100 meters between points was efficient in the evaluation of the spatial variability. It was verified the existence of a negative correlation between the variable protein content and bed bug attack and a significant correlation between the intensity of bed bug damage and the protein content with the variables related to seed quality. Physiological quality is not uniform, particularly in relation to vigor, providing better diagnosis through interpolation maps. Precision agriculture, coupled with the monitoring of seed quality during storage, indicated spatial variability of quality from harvest to the end of storage. Areas with high rates of bedbug and unit damage presented low quality physiology and reduced protein levels. The geostatistics allows to determine the spatial distribution of the physiological quality of soybean seeds in the area of seed production, facilitating the decision making, regarding the areas to be harvested.
\end{abstract}

Keywords: Vigor. Glycine max. Spatial variability. Precision farming. Seed production. Geostatistics.

\section{DISTRIBUIÇÃO ESPACIAL DO POTENCIAL DE ARMAZENAMENTO DE SEMENTES DE SOJA}

RESUMO - Objetivou-se identificar a distribuição espacial da qualidade fisiológica de sementes de soja durante o armazenamento, provenientes de campo de produção de 39 hectares por meio de técnicas de geoestatística na safra 2012/2013. Realizou-se amostragem de sementes em pontos georreferenciados, para a determinação da qualidade fisiológica e análise da dependência espacial. Os resultados foram submetidos às análises de estatística descritiva, correlação linear de Pearson e geoestatística. O grid de um ponto por hectare e uma malha de amostragem georreferenciada com espaçamento de 100 metros entre pontos foi eficiente na avaliação da variabilidade espacial. Constatou-se a existência de correlação negativa entre a variável teor de proteína e ataque de percevejos e correlação significativa entre a intensidade de dano por percevejo e o teor de proteína com as variáveis relacionadas a qualidade de sementes. A qualidade fisiológica não é uniforme, particularmente em relação ao vigor, proporcionando melhor diagnóstico por meio de mapas de interpolação. A agricultura de precisão, associada ao monitoramento da qualidade de sementes durante o armazenamento, indicou variabilidade espacial da qualidade desde a colheita até o fim do armazenamento. Áreas com altos índices de danos por percevejo e unidade apresentaram baixa qualidade fisiologia e reduzidos teores de proteína. A geoestatística possibilita determinar a distribuição espacial da qualidade fisiológica de sementes de soja em área de produção de sementes, facilitando a tomada de decisão, no que se refere às áreas a serem colhidas.

Palavras-chave: Vigor. Geoestatística. Glycine max. Produção de sementes. Variabilidade espacial.

\footnotetext{
${ }^{*}$ Corresponding author

${ }^{1}$ Received for publication in 08/21/2019; accepted in 01/27/2019.

${ }^{2}$ Crop Science Departament, Universidade Federal de Pelotas, Pelotas, RS, Brazil; agrorafaelvergara@gmail.com - ORCID: 0000-00030773-9038.

${ }^{3}$ Universidade Regional Integrada do Alto Uruguai e Missões, Frederico Westphalen, RS, Brazil; agazolla@uri.edu.br - ORCID: 00000002-1575-285X.

${ }^{4}$ Engineering Center, Universidade Federal de Pelotas, Pelotas, RS, Brazil; gizele.gadotti@ufpel.edu.br - ORCID: 0000-0001-9545-6577.
} 


\section{INTRODUCTION}

The soybean (Glycine max L. Merryl) is currently one of the main commodities of Brazilian agribusiness, which has become a source of income and prosperity for many producing regions of the country (BORLACHENCO; GONÇALVES, 2017; ARTUZO et al., 2018). In the 2017/2018-crop season, soybean presented a seeded area of 35,022.8 hectares with an average productivity of $3.156 \mathrm{~kg} \mathrm{ha} \mathrm{ha}^{-1}$, and these values have values increasing in recent years (CONAB, 2018).

To obtain larger productivity in soybean, seed quality plays a fundamental role because seeds of higher quality tend to generate more productive fields (SCHEEREN et al., 2010). One of the problems of soybean storage is seed deterioration. For Cardoso, Binotti and Cardoso (2012), deterioration is inevitable but can be the retarded depending on storage conditions and seed characteristics. In relation to seed storage, it is known that the factors that influence the conservation of the physiological potential are the initial quality and water content of the seeds, the relative humidity of the air and the temperature of the storage environment (FORTI; CICERO; PINTO, 2010). Thus, the initial vigor of the lot, especially as it pertains to latent damage, which significantly affects seed quality throughout storage, has a substantial impact on the seed storage potential.

A decrease in seed quality can translate to a decrease in the percentage of germination, an increase in abnormal seedlings and a reduction in the vigor of seedlings (TOLEDO et al., 2009). Thus, the storage potential of a seed is further influenced by the genetic characteristics of the species and the environmental factors present during seed development, harvesting, processing and storage (GRIS et al., 2010). Using precision agriculture techniques in a field of soybean seed production, Gazolla-Neto et al. (2015) concluded that physiological quality, especially as it relates to seed vigor, is not uniform throughout the production area.

In precision agriculture, the soil is no longer treated as homogeneous, and its spatial variability is explored and monitored for productive characteristics; thus, precision agriculture is a management strategy that seeks to rationalize the use of inputs such as pesticides and fertilizers and therefore is associated with the conservation of natural resources (MESTAS et al., 2010; SOUZA et al., 2010). Characterizing spatial variability features can improve the efficiency of the crop production system.

In this context, the current objective was to identify the spatial distribution of the physiological quality of soybean seeds during storage using geostatistical techniques.

\section{MATERIAL AND METHODS}

The work was conducted in the field production of soybean seeds in the municipality of São Gabriel - RS - Brazil (latitude 30 19'55"S, longitude $54^{\circ} 11^{\prime} 06^{\prime \prime} \mathrm{W}$ ) in an area of 39 ha during the 2012/2013-harvest season. Quality analyses of the seeds were carried out in the Didactic Laboratory of the Graduate Program Seed Analysis for Seed Science and Technology, University Federal de Pelotas.

Based on a contour map of the study area monitoring points were distributed within $100 \times 100$ meters. A central sample point was set up such that four subpoints, with an angle of $90^{\circ}$ between them, were distributed within 15 meters of the central point (Figure 1).

The central sampling points were set based on the methodology of systematic sampling, following a regular sampling mesh, whose points are demarcated, in a predefined path and based on the contour of the production area (MATTIONI; SCHUCH; VILLELA, 2011).

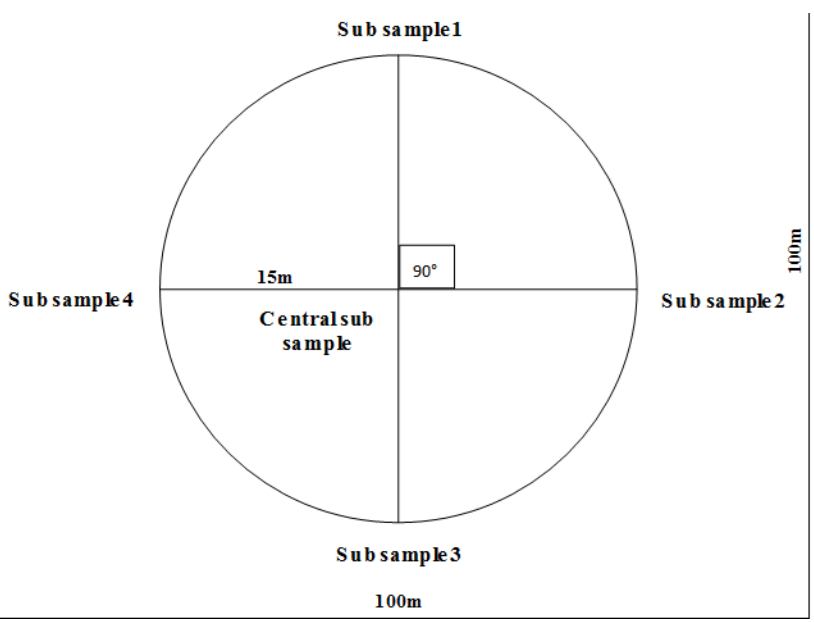

Figure 1. Diagram of systematic sampling with the central point and subpoints samples in the soybean production area 2012/2013-crop. 
No-till sowing in straw was conducted on November 5, 2012, using a seeder equipped with a machete-type furrower and a perforated disc-type seed distribution system. The machine (cultivar TEC 5936 IPRO) is regulated to distribute 15 soybean seeds per linear meter with spacing of $0.45 \mathrm{~m}$. The basic fertilization consisted of a fixed dose of $160 \mathrm{~kg}$ $\mathrm{ha}^{-1}$ of fertilizer $\mathrm{N}-\mathrm{P}_{2} \mathrm{O}_{5}-\mathrm{K}_{2} \mathrm{O}(02-20-20)$.

Seed harvest was performed when seeds had $17 \%$ water content; they were shelled, dried to $12 \%$ and stored in a controlled temperature environment for 180 days. The cultivar TEC 5936 IPRO completed the cycle between emergence and physiological maturity in 115 days, and the cycle between emergence and harvest, in 123 days.

To determine the quality of the seeds in the field, samples were collected from plants, taking from five portions of $1 \mathrm{~m}^{2}$ each, with the five subsamples forming the mean point sample. The plants had their seed pods separated and were subjected to manual threshing, following which the seed samples were collected from all points of the sampling mesh. The seed samples were submitted to artificial drying via placement in an oven with forced air circulation, at a temperature of $30^{\circ} \mathrm{C}$, until a contained water content of $12 \%$ was obtained (PESKE; BARROS; SCHUCH, 2012).

For the determination of seed quality, the following ratings were determined:

First, a germination count (GPC) and germination test $(\mathrm{G})$ were conducted in eight subsamples of 50 seeds. Seeds were formed into rolls consisting of three sheets of paper (Germitest ${ }^{\circledR}$ ) and moistened with water equivalent to 2.5 times the weight of the dry paper. The rolls were transferred to a growth chamber at $25^{\circ} \mathrm{C}$. Evaluations were made on the fifth and eighth days after sowing, and the results are expressed as a percentage of normal seedlings (BRASIL, 2009).

Emergence: made with eight subsamples of 50 seeds from each sampling point, distributed in grooves of $1.0 \mathrm{~m}$ in length and $2.5 \mathrm{~cm}$ in depth, with $0.5 \mathrm{~m}$ spacing between rows. Seeds were sowed in flowerbeds containing sand washed in the interior of a greenhouse at the recommended sowing time for the cultivar. The counts were performed daily at the same time since the epicotyls broke the surface of the sand up until 14 days after sowing, following which the percentage of emergence was calculated (NAKAGAWA, 1999).

Tetrazolium test: two subsamples of 50 seeds, arranged between three sheets of paper towels $\left(\right.$ Germitest $\left.^{\circledR}\right)$, moistened with distilled water and preconditioned for 16 hours in an incubator (BOD) at $25^{\circ} \mathrm{C}$. After incubation, the seeds were transferred to 50-mL plastic cups, within which they were completely submerged in tetrazolium solution $(0.075 \%)$, and then kept at $40^{\circ} \mathrm{C}$ for 180 minutes inside the BOD. After undergoing staining and washing with running water, the seeds were separated into classes 1 through 8 . The viability (VBT) was represented by the sum of the percentages of seeds belonging to classes 1 through 5 ; the level of vigor (VT), by the sum of the percentages of seeds belonging to classes 1 through 3 ; and the nonviability, by the sum of the percentages belonging to classes 6 through 8 . The potential for vigor and viability was expressed in percentage format (FRANÇA-NETO; KRZYZANOWSKI; COSTA, 1998).

Accelerated aging: the seeds were placed in a single layer on a canvas packed inside a plastic box, over $40 \mathrm{~mL}$ of water, and maintained at $41^{\circ} \mathrm{C}$ for 48 hours (MARCOS FILHO, 2015) and 72 hours (AOSA, 2002). The germination test was conducted posteriorly by performing a single count on the fifth day. The results were expressed as percentages.

Protein: The protein determination was carried out by the Kjeldahl method, as described in Association of Official Analytical Chemist (1975).

The results were analyzed using Pearson's linear correlation and geostatistical analysis. The descriptive statistics and Pearson correlation coefficients were generated using the statistical software Winstat. For Pearson's linear correlation, the criteria proposed by Dancey and Reidy (2006) were used, such that values below 0.3 indicated low correlation, values between 0.3 and 0.7 indicated moderate correlation and values above 0.7 indicated strong correlation. The geostatistical modeling and validation were performed using maps generated within the software program "Sistema Agropecuário CR - Campeiro 7" (GIOTTO; ROBAINA SULZBACK, 2007). Kriging, a geostatistical method of interpolation, was used in the preparation of the isoline maps, with a maximum survey radius of 100 $\mathrm{m}$.

For the classification of the spatial variability of analyzed variables, the criteria proposed by Wilding; Drees (1983) were used, such that a coefficient of variation (CV) less than $15 \%$ indicated low variability; a CV between $15 \%$ and $35 \%$ indicated moderate variability; and a $\mathrm{CV}$ above $35 \%$ indicated high variability.

The degree of spatial dependence (GDE) was defined according to Cambardella et al. (1994), wherein $\mathrm{C}_{0}$ was the nugget effect and $\mathrm{C}_{0}+\mathrm{C}$ was the level that defined values of $\left(\mathrm{C}_{0} / \mathrm{C}_{0}+\mathrm{C} 1\right) 100$. GDE values less than $25 \%$ indicated a strong degree of spatial dependence; GDE values between $25 \%$ and $75 \%$ indicated a moderate degree of spatial dependence; and GDE values above $75 \%$ indicated a weak degree of spatial dependence.

\section{RESULTS AND DISCUSSION}

Table 1 presents the results of emergence of seedlings in sand, germination on paper and first count of germination during seed storage, along with 
the results of accelerated aging over 48 and 72 hours and percentage of protein and emergence at 180 days of storage. The average values of germination and emergence in sand were higher than $90 \%$, with a coefficient of variation of less than $2.5 \%$. Similarly, the average accelerated aging over 48 hours was $94.00 \%$ and over 72 hours was $91.51 \%$, indicating the seeds were of high physiological quality.

In a similar study, Mondo et al. (2012a) obtained a germination average of $87.67 \%$, with maximum and minimum values of $98 \%$ and $73 \%$, respectively, and a $\mathrm{CV}$ of $7.25 \%$. The results obtained in this study may be related to the favorable climatic conditions occurring in the R7 and R8 (reproductive stages related to the end of seed filling), as well as to the $17 \%$ moisture content at harvest and to the subsequent artificial drying and manual seed track. After physiological maturity, the seed is physiologically disconnected from the mother plant, facing exposure to ambient conditions, which may be unfavorable (PESKE; BARROS; SCHUCH, 2012); it is therefore recommended to initiate harvest only when seeds contain water content between 18 and $17 \%$ (DALTRO et al., 2010).

Table 1. Maximum, minimum, mean, standard deviation (SD), coefficient of variation (CV), range and degree of spatial dependence (GDE) of agronomic attributes and soybean seed quality during storage.

\begin{tabular}{l|ccccccccc}
\hline & Maximum & Minimum & Mean & SD (\%) & CV (\%) & $\begin{array}{c}\text { Range } \\
(\mathrm{m})\end{array}$ & $\begin{array}{c}\text { GDE } \\
\begin{array}{c}\text { Nugget } \\
\text { effect }\end{array}\end{array}$ & $\mathrm{R}^{2}$ \\
\hline G 0 D (\%) & 100 & 92 & 97.5 & 1.4 & 1.48 & 200 & 63.9 & 1.3391 & 0.9989 \\
G 60 D (\%) & 99 & 92 & 96.3 & 1.8 & 1.83 & 200 & 57.2 & 0.0350 & 0.9922 \\
G 120 D (\%) & 94 & 87 & 91.7 & 1.6 & 1.76 & 300 & 43.8 & 1.2289 & 0.9981 \\
G 180 D (\%) & 90 & 80 & 86.5 & 2.1 & 2.47 & 300 & 45.7 & 1.0241 & 0.9987 \\
FCG 0 D (\%) & 100 & 92 & 97.3 & 1.7 & 1.74 & 200 & 61.6 & 1.7748 & 0.9982 \\
FCG 60 D (\%) & 98 & 90 & 95.5 & 1.9 & 1.99 & 200 & 57.8 & 1.6282 & 0.9991 \\
FCG 120 D (\%) & 80 & 67 & 74.4 & 3.7 & 4.11 & 200 & 56.2 & 1.4238 & 0.9986 \\
FCG 180 D (\%) & 51 & 37 & 45.4 & 2.8 & 6.08 & 900 & 49.3 & 1.3182 & 0.9988 \\
Emergence 180 & 98 & 90 & 95.4 & 1.6 & 1.63 & 200 & 60.0 & 1.4455 & 0.9991 \\
D (\%) & 37.0 & 34.1 & 36.1 & 0.5 & 1.49 & 200 & 63.7 & 0.1854 & 0.9989 \\
Protein 0 D (\%) & 97 & 88 & 94.0 & 2.4 & 2.59 & 200 & 53.7 & 5.9512 & 0.9985 \\
A. A. 48 h (\%) & 94 & 87 & 91.5 & 1.8 & 2.01 & 200 & 53.4 & 1.8213 & 0.9989 \\
A. A. 72 h (\%) & 94 & & & & & & & &
\end{tabular}

G $0 \mathrm{D}=$ germination in paper at zero storage days; $\mathrm{G} 60 \mathrm{D}=$ germination in paper with 60 days of storage; $\mathrm{G} 120 \mathrm{D}=$ germination in paper with 120 days of storage; $\mathrm{G} 180 \mathrm{D}=$ germination in paper with 180 days of storage; FCG O D = first germination count in paper at zero storage days; FCG $60 \mathrm{D}=$ first germination count on paper with 60 days of storage; FCG $120 \mathrm{D}=$ first germination count in paper with 120 days of storage; FCG $180 \mathrm{D}=$ first germination count on paper with 180 days of storage; Emergency $180 \mathrm{D}=$ emergence in soil at 180 days of storage; Protein $0 \mathrm{D}=$ protein percentage at zero storage days; A.A. $48 \mathrm{hs}(\%)=$ accelerated aging $48 \mathrm{hrs}$; A.A. $72 \mathrm{~h}(\%)=$ accelerated aging $72 \mathrm{~h}$.

The degree of spatial dependence of the variables was moderate, with values of 43.76 for germination at 180 days and 63.85 for germination at zero days (Table 1).

The analysis of the range results obtained for germination, first germination count, protein, emergence, and accelerated aging over 48 and 72 hours demonstrated that the point spacing used in the sampling grid, with one point per hectare, was effective for obtaining representative samples and for estimating seed quality and productivity (Table 1); similar results were obtained by Mattioni, Schuch and Villela (2011) and Corrêa et al. (2017).

The range represents the influence zone of an observation, reflecting the degree of homogeneity among samples, such that the higher the value is, the more homogeneous the process under study (ANDRIOTTI, 2013). In this context, reach values are fundamental in the planning of future samplings, allowing for an estimate of appropriate grid size and number of points to be sampled (SOUZA et al.,

\section{0; GAZOLLA-NETO et al., 2016).}

The maps of the spatial variability of accelerated aging of 48 hours in duration, emergence in sand, protein content, incidence of damage by humidity and bed bugs all had a $\mathrm{P}<0.05$. The results showed that the physiological quality of the seedlings showed adequate sensitivity to the identified variations within the production area (Figures 2 and 3). The interaction of the spatial variability of the variables, associated with the mapping, facilitated the mapping of regions containing high and low vigor seeds within the production area. The regions with high rates of bed bug damage and humidity presented reduced vigor and emergence at the time of harvest and during storage. Seeds with low vigor may cause reductions in emergence speed, uniformity, total emergence, initial size of the seedlings and establishment of appropriate stands (SCHUCH; KOLCHINSKI; FINATTO, 2009; SANTOS et al., 2011; MONDO et al., 2012b). 
The evaluation of the physiological potential of the seeds by interpolation of the spatial distribution map variables first count germination, protein content, emergence, accelerated aging over 48 hours (Figure 3 ) and germination during storage (Figure 4 and 5) presented a marked differentiation within the production area. These results provided evidence of uneven distribution of the physiological quality of seeds in the production area at the time of harvest and during the 180 days of storage, corroborating the findings of Mattioni, Schuch and
Villela (2011) and Mondo et al. (2012a). According to Peske, Barros and Schuch (2012), during the process of seed deterioration, loss of germination capacity is the last event to occur before seed death; in contrast, vigor tests are based on events that occur prior to loss of germination capacity. According to Mattioni, Schuch and Villela (2011), vigor tests allow for a better spatial diagnosis of the physiological quality of dssee since they offer greater sensitivity in the diagnosis of deterioration.

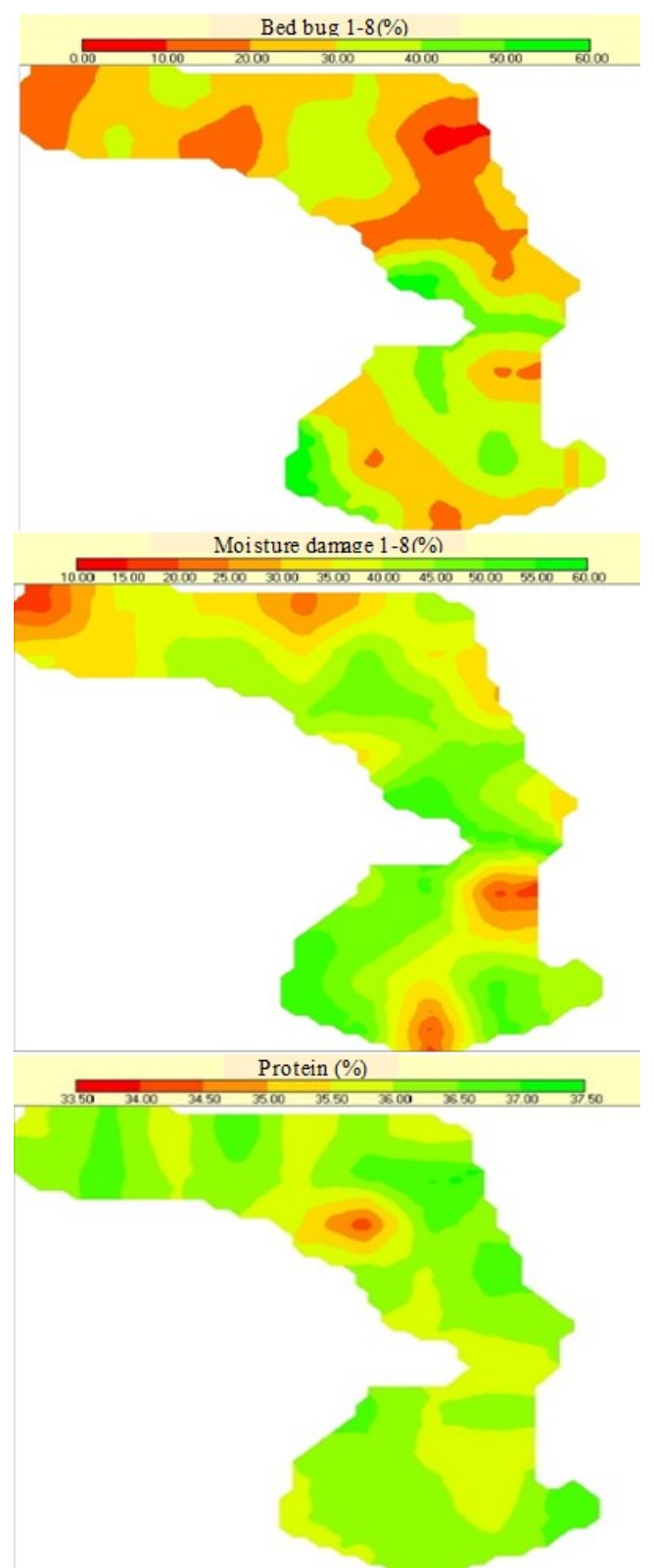

Figure 2. Maps of spatial variability of occurrence of bed bug and moisture damage, and protein content of soybean seeds in a production area. 


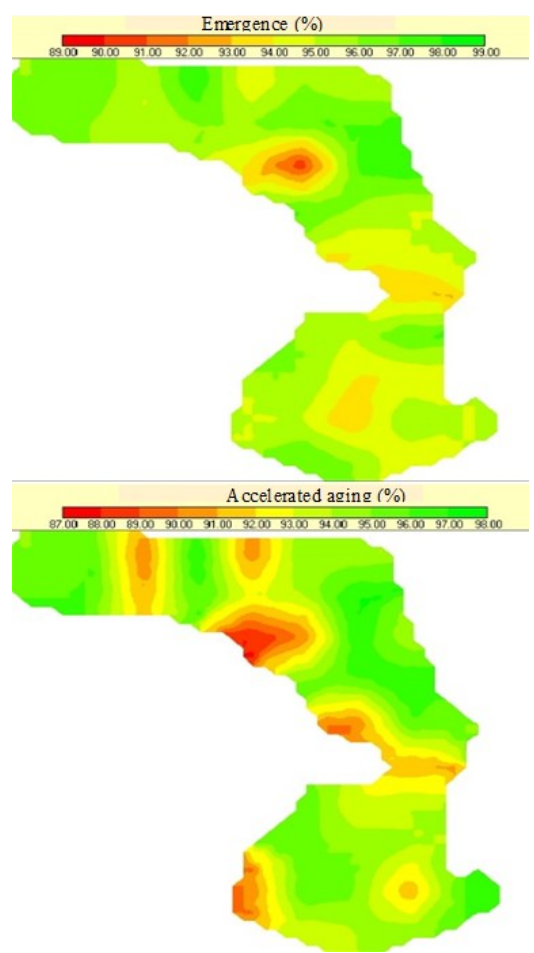

Figure 3. Spatial variability maps of emergence and accelerated aging of soybean seeds in a production area.

In Figure 4, the maps related to the germination variable of the production area are set at 0 and 60 days of storage. It was observed that in the measurements of initial quality, the variation in germination was of low intensity, and thus, there was only a small region in the germination map where the germination was strongly influenced by the location. However, when the germination map was observed at 60 days of storage, there was an increase in heterogeneity in the behavior of the variable, thus resulting in a greater distinction between the collection regions. It is worth emphasizing that the region where the lowest germination level was observed at zero storage days presented greater spatial variability (increase in area) and intensity at 60 days of storage.

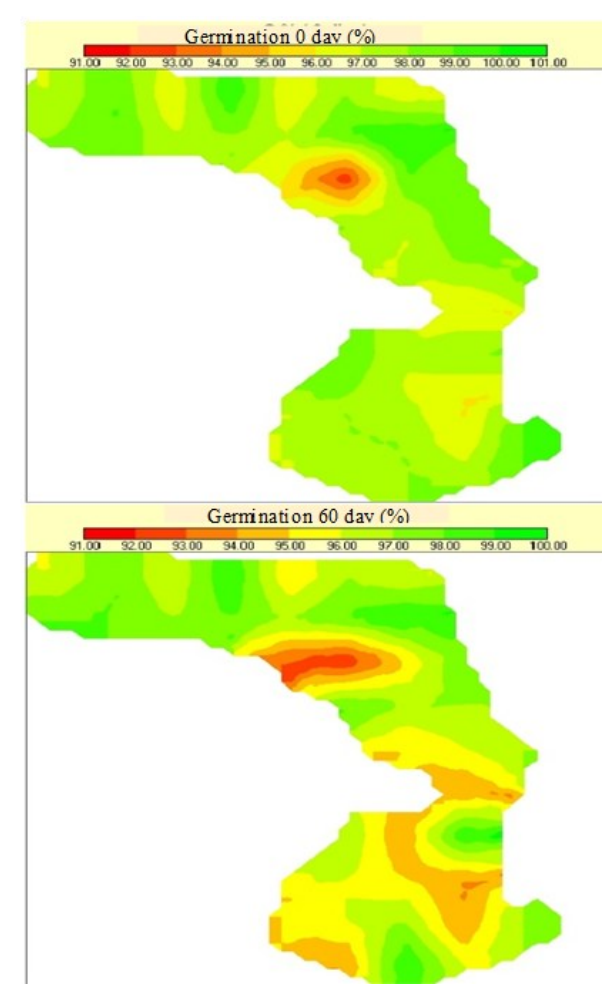

Figure 4. Spatial variability maps of the paper germination test $(\mathrm{G} \%)$ of soybean seeds in a production area at 0 and 60 days of storage. 
The behavior of the germination variable at 120 and 180 days of storage (Figure 5) was similar to that observed in the initial quality variable. Thus, the regions of the production area that presented lower germination levels had the lowest seed qualities during storage. However, there was greater amplitude between the points of maximum and minimum germination and higher heterogeneity within the area than was observed with the initial quality variable.

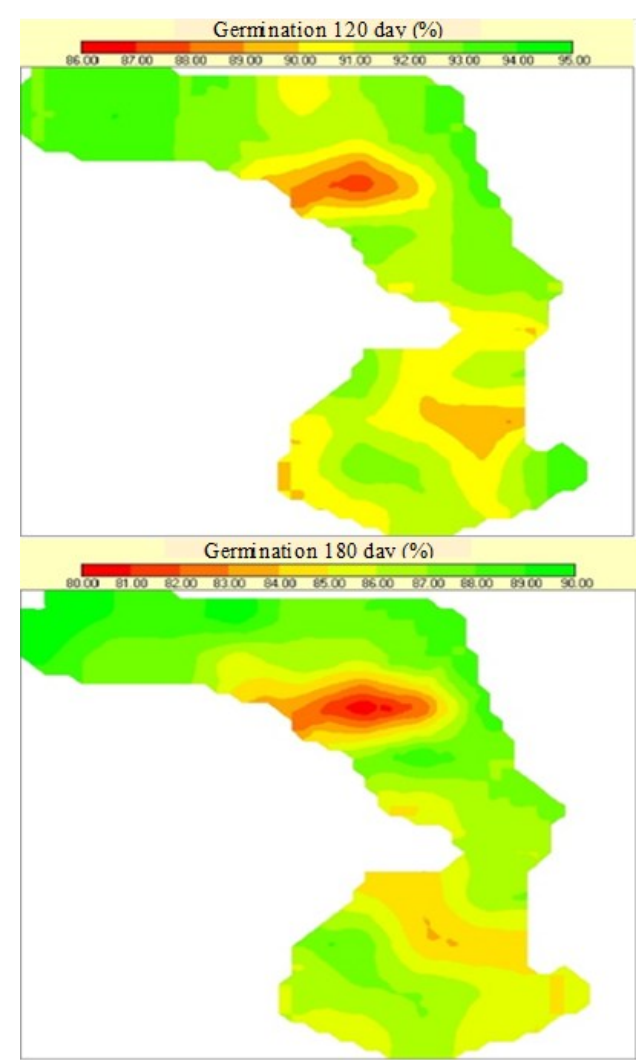

Figure 5. Spatial variability maps of the germination test $(\mathrm{G} \%)$ in paper $(\mathrm{G} \%)$ of soybean seeds in a production area at 120 and 180 days of storage.

It was observed that the regions with the lowest levels of germination in the initial quality presented the worst values for germination at the end of storage (Figure 4 and 5). It is important to emphasize that the regions with lower germination levels increased in area during storage, indicating that germination was spatially dependent. There was an indication that isolated situations occurred within the production area that resulted in the lowest level of germination of seeds.
The first germination count variable (Figure 6) showed similar behavior to germination. In the measurement of initial quality, isolated regions with values lower than the other regions were detected. At 60 days of storage, an increase in the area of the region, which initially showed the lowest values of first germination count, was observed. It is worth emphasizing that there was an increase in the amplitude between the maximum and minimum points. 


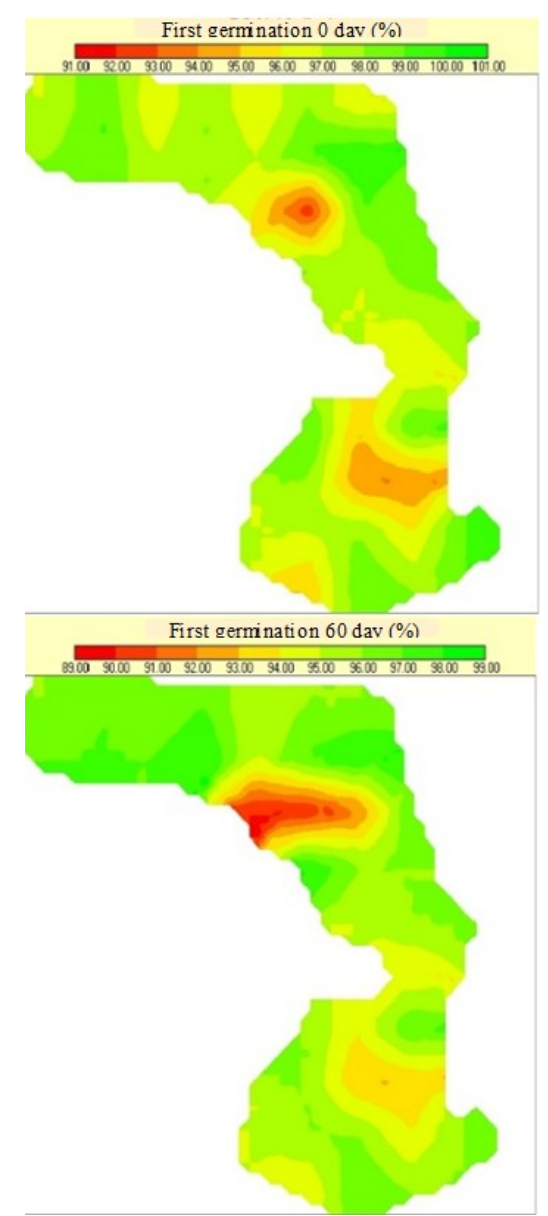

Figure 6. Spatial variability maps of the results of the first soybean germination count at 0 and 60 days of storage.

At 120 and 180 days of storage (Figure 7), there was a decrease in amplitude in the values of the first germination count. However, when comparing the maps describing initial quality and quality at 60 days of storage, it is evident that the regions with the lowest levels of first germination count remained the regions with lowest values after 60 days of storage.

For the germination variable and the first germination count, the variability in seed quality obtained in the field of production tends to be maintained throughout the storage period. This fact is related to the initial quality of the seeds, wherein seeds of lower quality tend to present higher respiratory activity than seeds of higher quality, which in turn tends to intensify the amplitude between higher and lower quality seeds throughout the duration of storage.

The protein content of seeds, depicted in Table 2, correlates negatively with the level of bug attack on seeds; however, the protein content correlates positively with the initial seed vigor obtained by the accelerated aging test (EA 48). It was observed that during the studied storage periods, the seed protein content showed a significant and positive correlation with the variables related to physiological quality. This relationship is particularly true for the variable of emergence at 180 days of storage, where it is observed that an increase in protein content leads to noticeably higher emergence of seedlings. 


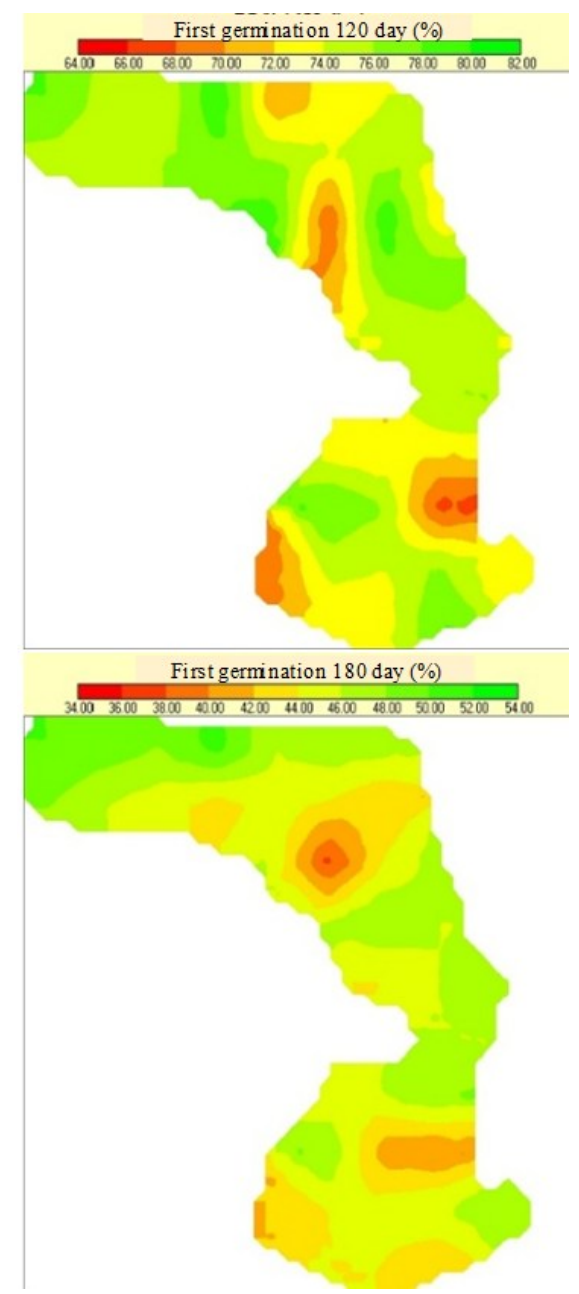

Figure 7. Spatial variability maps of the results of the first soybean germination count at 0 and 60 days of storage.

According to Carvalho and Nakagawa (2012), because the first biochemical event known to occur upon exposure to unfavorable environmental conditions is a decrease in protein synthesis, seeds with higher physiological quality have higher protein content. Studying the relationship between protein content and physiological quality of rice seeds, Bortolotto et al. (2008) observed that measurements of protein content can identify differences in quality between seed lots with different levels of physiological potential and can be correlated with seed emergence in the field. The authors further reported protein assessment as a promising finding for association with conventional tests. Working with different management methods of nitrogen fertilization in bean and wheat plants, Gomes Junior and Sá (2010) and Favarato et al. (2012), respectively, observed that seeds with higher protein content were seeds of higher physiological quality.

Figure 1 shows the unevenness found in protein content in the samples collected in the field of production. Table 2 shows that the protein content present in the seeds correlates significantly with the physiological quality during storage; this observation is in agreement with the findings of several authors (HENNING et al., 2010; GOMES JUNIOR; SÁ, 2010; CARVALHO; NAKAGAWA, 2012). Therefore, seeds with high protein content tend to present better storage potential and, consequently, higher quality seeds at the end of the storage period. 
Table 2. Pearson Linear correlation for variables related to protein content (P), bed bug damage (BD), initial vigor (AA 48 and AA 72), germination along storage ( $\mathrm{G} 0, \mathrm{G} 60, \mathrm{G} 120, \mathrm{G} \mathrm{180)}$, first germination count along storage (FCG 0 , FCG 60) and end of storage emergency $(\mathrm{E})$.

\begin{tabular}{c|cccccccccccc}
\hline & $\mathbf{P}$ & BD & AA 48 & AA 72 & G 0 & FCG 0 & G 60 & FCG 60 & G 120 & F 180 & E \\
\hline $\mathbf{P}$ & $-0.465^{*}$ & -0.211 & $0.746^{* *}$ & $0.703^{* *}$ & $0.999^{* *}$ & $0.874^{* *}$ & 0.208 & $0.759^{* *}$ & $0.659^{* *}$ & $0.652^{* *}$ & $0.708^{* *}$ \\
$\mathbf{B D}$ & - & & & & & & & & & & & \\
\hline
\end{tabular}

**significant at $1 \%$ level; * significant at the level of $5 \%$.

The incidence of damage caused by bedbugs (Table 2) showed a positive and significant correlation with the occurrence of damage due to moisture. This fact can be attributed to the perforation caused by the insertion of the insect's stylus, which may leave the seed with greater exposure to the elements, including climatic changes, particularly variations in humidity in the environment.

The occurrence of bedbug damage (Table 2) showed significant and negative correlation with the variables related to seed quality during storage. It is worth emphasizing that the vigor analyzed through accelerated aging showed a negative correlation with the level of bedbug damage, and the vigor of seedlings after storage (EF) showed a negative correlation with the level of damage caused by bed bug attacks. Thus, higher incidences of damage caused by bedbugs tend to coincide with a decrease in the initial force and level of emergence of seedlings after storage.

Studying the physical, chemical and physiological quality of soybean seeds produced in six regions, Costa et al. (2005) found similar results, noting that the results obtained by the correlation and linear regression analyses indicated that soybeans damaged by bed bugs had shown reductions in germination and vigor. The authors also indicate that the results for the correlation and linear regression analyses show that with marked rates of tegument rupture, mechanical damage, moisture deterioration, and bed bug lesions, a consistent decline in germination seed vigor occurred.

It is noted that the damage caused by insect bites, depending on the location and extent of lesions, such as the axis-embryonic region, makes the seed incapable of germination since this region is critical in metabolic processes because it is where major growth structures that give rise to the future seedlings are located (FRANÇA-NETO; KRZYZANOWSKI; COSTA, 1998).

From the above findings, the existence of heterogeneity in the production area with respect to protein content, moisture damage and bed bug attack can result in a heterogeneous storage environment.
Therefore, in a given storage environment, there will be seeds with higher levels of deterioration than others.

It is noteworthy that seeds with high levels of deterioration tend to exhibit increased respiratory activity, which in turn tends to release more $\mathrm{CO}_{2}$, $\mathrm{H}_{2} \mathrm{O}$ and energy in the form of heat into the storage environment. This reaction occurs in the chain and must compromise the medium-long term storage potential of the seeds of higher integrity, consequently resulting in seeds of lower physiological potential.

\section{CONCLUSIONS}

There is spatial variability in storage potential in a field of soybean seed production.

The physiological quality of seeds in different positions in a field of soybeans is not uniform, particularly in relation to the levels of moisture damage and bed bug attack, which result in lower storage potential when present.

There is a positive relationship between the protein content in soybean seeds and the physiological quality maintained throughout storage, especially as it concerns variables related to vigor.

\section{REFERENCE}

ANDRIOTTI, J. L. S. Fundamentos de estatística e geoestatística. 1. ed. São Leopoldo, RS: UNISINOS, 2013, 102 p.

ARTUZO, F. D. et al. Gestão de custos na produção de milho e soja. Revista Brasileira de Gestão de Negócios, v. 20, n. 2, p. 273-294, 2018.

ASSOCIATION OF OFFICIAL ANALYTICAL CHEMISTS - AOAC. Official methods of analysis. Washington, 1975. $1054 \mathrm{p}$.

ASSOCIATION OF OFFICIAL SEED ANALYSTS - AOSA. Seed vigor testing handbook. Stillwater: 
2002. 88 p. (Contribution, 32).

BORLACHENCO, N. G. C.; GONÇALVES, A. B. Expansão agrícola: Elaboração de indicadores de sustentabilidade nas cadeias produtivas de Mato Grosso do Sul. Interações, v. 18, n. 1, p. 119-128, 2017.

BORTOLOTTO, R. P. et al. Teor de proteína e qualidade fisiológica de sementes de arroz. Bragantia, v. 67, n. 2, p. 513-520, 2008.

BRASIL. Ministério da Agricultura, Pecuária e Abastecimento. Regras para análise de sementes. Brasília: SDA/ACS, 2009. 399 p.

CAMBARDELLA, C. A. et al. Field-scale variability of soil properties in central Iowa soils. Soil Science Society of America Journal, v. 58, n. 5, p. 1501-1511, 1994.

CARDOSO, R. B.; BINOTTI, F. F. DA S.; CARDOSO, E. D. Potencial fisiológico de sementes de crambe em função de embalagens e armazenamento. Pesquisa Agropecuária Tropical, v. 42 , n. 3 , p. $272-278,2012$.

CARVAlHO, N. M.; NAKAGAWA, J. Sementes: ciência, tecnologia e produção. 5. ed. Jaboticabal, SP: FUNEP, 2012. 590 p.

\section{COMPANHIA}

NACIONAL

DE ABASTECIMENTO - CONAB. Acompanhamento da safra brasileira de grãos - Safra 2017/18. Quinto Levantamento, Fevereiro 2018. Brasília, 2018. p. 1-140.

CORRÊA, M. F. et al. Variabilidade espacial dos atributos químicos e agronômicos do solo em campo de produção de sementes de trigo. Scientia Agraria Paranaensis, v. 16, n. 4, p. 500-509, 2017.

COSTA, N. P. et al. Perfil dos aspectos físicos, físiológicos e químicos de sementes de soja produzidas em seis regiões do Brasil. Revista Brasileira de Sementes, v. 27, n. 2, p. 172-181, 2005.

DALTRO, E. M. F. et al. Dessecação em précolheita de sementes de soja. Revista Brasileira de Sementes, v. 32, n. 1, p. 111-122, 2010.

DANCEY, C. P.; REIDY, J. Análise de correlação: o r de Pearson. In: DANCEY, C. P, REIDY, J. (Eds.). Estatística sem matemática para psicologia. Porto Alegre, RS: Artemed, 2006. cap. 5, p. 178-216.

FAVARATO, L. F. et al. Adubação nitrogenada e qualidade fisiológica de sementes de trigo. Bragantia, v. 71, n. 1, p. 371-379, 2012.
FORTI, V. A.; CICERO, S. M.; PINTO, T. L. F. Avaliação da evolução de danos por "umidade" e redução do vigor em sementes de soja, cultivar TMG113-RR, durante o armazenamento, utilizando imagens de raios $\mathrm{x}$ e testes de potencial fisiológico. Revista Brasileira de Sementes, v. 32, n. 3, p. 123 133,2010

FRANÇA-NETO, J. B.; KRZYZANOWSKI, F. C.; COSTA, N. P. The tetrazolium test for soybean seeds. Londrina, PR: EMBRAPA-CNPSo, 1998. 72 p.

GAZOLLA-NETO, A. et al. Spatial distribution of physiological quality of soybean seed production field. Revista Caatinga, v. 28, n. 3, p. 119-127, 2015 .

GAZOLLA-NETO, A. et al. Spatial distribution of the chemical properties of the soil and of soybean yield in the field. Revista Ciência Agronômica, v. 47 , n. 2 , p. $325-333,2016$

GIOTTO, L.; ROBAINA, A. D.; SULZBACH, L. A. Agricultura de precisão com o sistema CR Campeiro 6. Santa Maria, RS: FATEC/UFSM, 2007. $330 \mathrm{p}$.

GOMES JUNIOR, F. G.; SÁ, M. E. Qualidade de sementes de feijão e adubação nitrogenada. Revista Brasileira de Sementes, v. 32, n. 1 p. 34-44, 2010.

GRIS, C. F. et al. Qualidade fisiológica e teor de lignina no tegumento de sementes de soja convencional e transgênica RR submetidas a diferentes épocas de colheita. Ciência e Agrotecnologia, v. 34, n. 2, p. 374-381, 2010

HENNING, F. A. et al. Composição química e mobilização de reservas em sementes de soja de alto e baixo vigor. Bragantia, v. 69, n. 10, p. 727-734, 2010

MARCOS FILHO, J. Fisiologia de sementes de plantas cultivadas. Londrina, PR: ABRATES, 2015. $660 \mathrm{p}$.

MATTIONI, N. M.; SCHUCH, L. O. B.; VILLELA, F. A. Variabilidade espacial da produtividade e da qualidade das sementes de soja em um campo de produção. Revista Brasileira de Sementes, v. 33, n. 4, p. 608-615, 2011.

MESTAS, R. M. et al. Variabilidad espacial de los atributos físico-hídricos del suelo y de la productividad del cultivo de fréjol (Phaseolus vulgaris L) irrigado bajo un sistema de siembra directa. Revista de Ciências Agrárias, v. 33, n. 1, p. 307-313, 2010. 
MONDO, V. H. V. et al. Spatial variability of soil fertility and its relationship with seed physiological potential in a soybean production area. Revista Brasileira de Sementes, v. 34, n. 2, p. 193-201, 2012a.

MONDO, V. H. V. et al. Vigor de sementes e desempenho de plantas de milho. Revista Brasileira de Sementes, v. 34, n. 1, p. 143-155, 2012 b.

NAKAGAWA, J. Testes de vigor baseados no desempenho das plântulas. In: KRZYZANOSKI, F. C.; VIEIRA, R. D.; FRANÇA NETO, J. B. (Eds.). Vigor de sementes: conceitos e testes. Londrina, PR: ABRATES, 1999. cap 2, p. 20-24.

PESKE, S. T.; BARROS, A. C. S. A; SCHUCH, L. O. B. Produção de Sementes. In: PESKE, S. T.; VILLELA, F. A.; MENEGHELlO, G. E. (Eds.). Sementes: fundamentos científicos e tecnológicos. Pelotas, RS: Universitária, 2012, cap. 2, p. 13-100.

SANTOS, J. F. et al. Avaliação do potencial fisiológico de lotes de sementes de soja. Revista Brasileira de Sementes, v. 33, n. 4, p. 743-751, 2011.

SCHEEREN, B. R. et al. Qualidade fisiológica e produtividade de sementes de soja. Revista Brasileira de Sementes, v. 32, n. 3, p. 35-41, 2010.

SCHUCH, L. O. B.; KOLCHINSKI, E. M.; FINATTO, J. A. Qualidade fisiológica da semente e desempenho de plantas isoladas em soja. Revista Brasileira de Sementes, v. 31, n. 1, p. 144-149, 2009.

SOUZA, C. M. A. et al. Espacialização de perdas e da qualidade do feijão em colheita semimecanizada. Acta Scientiarum. Agronomy, v. 32, n. 2, p. 201208, 2010.

TOLEDO, M. Z. et al. Qualidade fisiológica e armazenamento de sementes de feijão em função da aplicação tardia de nitrogênio em cobertura. Pesquisa Agropecuária Tropical, v. 39, n. 2, p. 124 $-133,2009$.

WILDING, L. P.; DREES, L. R. Spatial variability and pedology. In: WILDING, L. P.; SMECK, N. E.; HALL, G. F. (Eds.). Pedogenesis and soil taxonomy. Amsterdam: Elsevier Science, 1983. v. 1, cap. 4 , p. $83-116$. 